\title{
Collective nectar foraging at low reward conditions in honeybees Apis mellifera ${ }^{1}$
}

\author{
Patricia Carina FERNÁNDEZ*, Walter Marcelo FARINA \\ Grupo de Estudio de Insectos Sociales, IFIBYNE-CONICET, Departamento de Fisiología, \\ Biología Molecular y Celular, Facultad de Ciencias Exactas y Naturales, Universidad de Buenos Aires, \\ Pabellón II, Ciudad Universitaria, (C1428EHA) Buenos Aires, Argentina \\ Received 4 May 2004 - Revised 7 September 2004 - Accepted 4 November 2004 \\ Published online 1 June 2005
}

\begin{abstract}
The individual behavior of foraging bees was analysed at low-reward conditions within a collective context. This study compared bee's foraging behavior under non-competitive (individual) and highly competitive (collective) conditions. A regular pattern in the visitation, non-visitation times and the frequency of foraging bouts was observed in bees that collected individually. In contrast, when bees foraged collectively, they demonstrated great variability in their behaviors. Some bees had regular visits to the feeder while others had only sporadic bouts. Individual foraging parameters related to the "persistency" at the feeder were well correlated with the prior foraging experience at this site. Results suggests that prior experience at a feeding place and efficiency as nectar carriers are positively correlated during collective foraging.
\end{abstract}

Apis mellifera / foraging / experience / collective foraging / competition

\section{INTRODUCTION}

Cooperative behavior in social insects is part of a complex system in which factors, such as the internal state of the colony and its individuals, communication signals, and environmental variables, influence individual task performance. Cooperative activities are often regulated by collective decisions that emerge through decentralized systems of control, which allow for flexibly adjusting their activities in response to environmental challenges (Seeley, 1995; Beshers et al., 1999; Camazine et al., 2001). Numerous examples show how complex abilities, such as selectively exploiting the most profitable patches of flowers, or deciding on the best nest site from a dozen or more possibilities, emerge from the behavior of individual bees (Seeley et al., 1991; Camazine et al., 1999; Seeley and Visscher, 2004). Therefore, it is necessary to analyze individual behaviors in the collective context. It is widely known that bees possess the ability to finely adjust several components of their foraging behavior according to the quality of the nectar source (Núñez, 1970, 1982; Seeley et al., 1991; Seeley, 1995). Several works pointed out the effect of the nectar flow rate and concentration, nutritional state of the colony, genetic constitution and other variables on the foraging behavior of individual bees (Núñez, 1970, 1982; Seeley, 1995; Seeley et al., 1991; Oldroyd et al., 1992). However, little is known about how bee foraging behavior is affected by

* Corresponding author: pfernan@ zedat.fu-berlin.de

Present address: Freie Universität Berlin, Institut für Angewandte Zoologie- Ökologie der Tiere, HaderslebenerStr. 9, (14163) Berlin, Germany.

${ }^{1}$ Manuscript editor: Marla Spivak 
the presence of other foragers at the food source. This variable could be relevant because it was shown that the spatial foraging pattern in bumblebees is determined, in part, by the presence of other bumblebees foraging simultaneously (Thomson et al., 1987; Makino and Sakai, 2004). Thus, this study examines individual behaviors when several honeybees forage together at a food source.

Nectar is produced in flowers at very low and variable rates and it is offered patchily in the field (Núñez, 1977; Vogel, 1983; Zimmerman, 1981). The abundance and distribution of this resource can vary both in space and time, as a result not only of the plant production rate but also of the foraging activity itself (Pleasants and Zimmerman, 1979, 1983; Zimmerman, 1981). At the same time, the foraging activity of the pollinators is directly affected by nectar availability. This situation can be simulated experimentally by using rate-feeders that deliver sugar solution at low rates (i.e. below the maximal bee's ingestion rate, Núñez, 1971a, b, 1982). Under these conditions, after the discovery of the food source by a bee, and as soon as the first recruits arrive, a foraging team is built up and a number of nestmates compete to collect the sucrose solution delivered (Núñez, 1973). Since more foragers are now involved, the reward offered is partitioned between the members of the foraging team. Thus, each bee returns to the hive with lower crop loads than under individual foraging conditions, decreasing the number of recruited bees at the feeder and their recruitment activity thereafter (Núñez, 1973). The goal of this study was to compare bee's foraging behavior under non-competitive (individual) and highly competitive (collective) foraging conditions. We also describe the first steps in the build up of a foraging team and the individual behavior of each of its members during the process.

Since a team of foragers may exploit the same food source on successive days, we registered the individual behaviors of the team members over different experimental days. This experimental situation led to having bees with different levels of experience at the ratefeeder each day. Since it was suggested that foraging experience influences individual and collective foraging patterns (von Frisch, 1967; Free, 1967; Dukas and Visscher, 1994; Gil and Farina, 2002), we also correlated parameters of the bee's individual behavior with the number of previous times that each forager had been exploiting the rate-feeder.

\section{MATERIALS AND METHODS}

Experiments were performed at the experimental field of the University of Buenos Aires ( $34^{\circ} 32^{\prime} \mathrm{S}$, $58^{\circ} 26^{\prime}$ W) from March to April 1999 and March 2001 when natural nectar sources were scarce. Experiments were conducted during this period to minimize competition with natural flowers. A colony consisting of a queen, brood and approximately 4000 workers of European bees (hybrid descendants of Apis mellifera ligustica bees) was located in a two-frame observation hive (see von Frisch, 1967).

\subsection{Procedure}

Approximately 40 bees were trained to collect scented sugar solution $(80 \mu \mathrm{L}$ almond essence per liter) at a rate-feeder located $160 \mathrm{~m}$ from the observation hive. Trained bees were individually labeled with a colored and numbered tag on the thorax. The rate-feeder had a single opening of $0.5-\mathrm{cm}$ diameter connected by a capillary tube to a pumping system that delivered $1.8 \mathrm{M}$ sucrose solution at a constant flow rate of $5.5 \mu \mathrm{L} / \mathrm{min}$. The feeder (henceforth: ratefeeder) allowed control of the solution flow rate, and is described in detail elsewhere (Núñez, 1971a). Scented solutions were used both during training and assay. The observation period took place between $1030 \mathrm{~h}$ and $1230 \mathrm{~h}$ in the morning and $1500 \mathrm{~h}$ and $1700 \mathrm{~h}$ in the afternoon. Assays always began with a single bee at the food source (henceforth: pioneer bee) while the others stayed in the hive. As soon as the pioneer bee found the reward at the rate-feeder, it returned to the colony and recruited hive-mates. The hive-mates that arrived and landed at the feeding platform were captured or allowed to forage freely leading to an open or closed loop condition respectively (see below). We defined these bees as "incoming bees". Open and closed loop conditions allowed us to control the avoidance or promotion of competition for resources, respectively, among employed foragers. We recorded each of the incoming bees that visited the feeder during a one-minute period throughout the 2-hours observation period to identify the employed bee, its time spent at the feeder and the group size at each recorded period. Unlabeled incoming bees were immediately marked with a spot of paint verifying their presence inside the observation hive in their next hive-stay. From the next day on, they were defined as bees that were familiar with the feeder (labeled bees). Therefore, the same labeled bee could be counted more than once during the season. 
Table I. Reward programs offered at the rate-feeder. All of them offered sucrose solution at a constant flow rate of $5.5 \mu \mathrm{L} / \mathrm{min}$ along a 2 -hour observation period. $\mathrm{N}=$ number of observation periods.

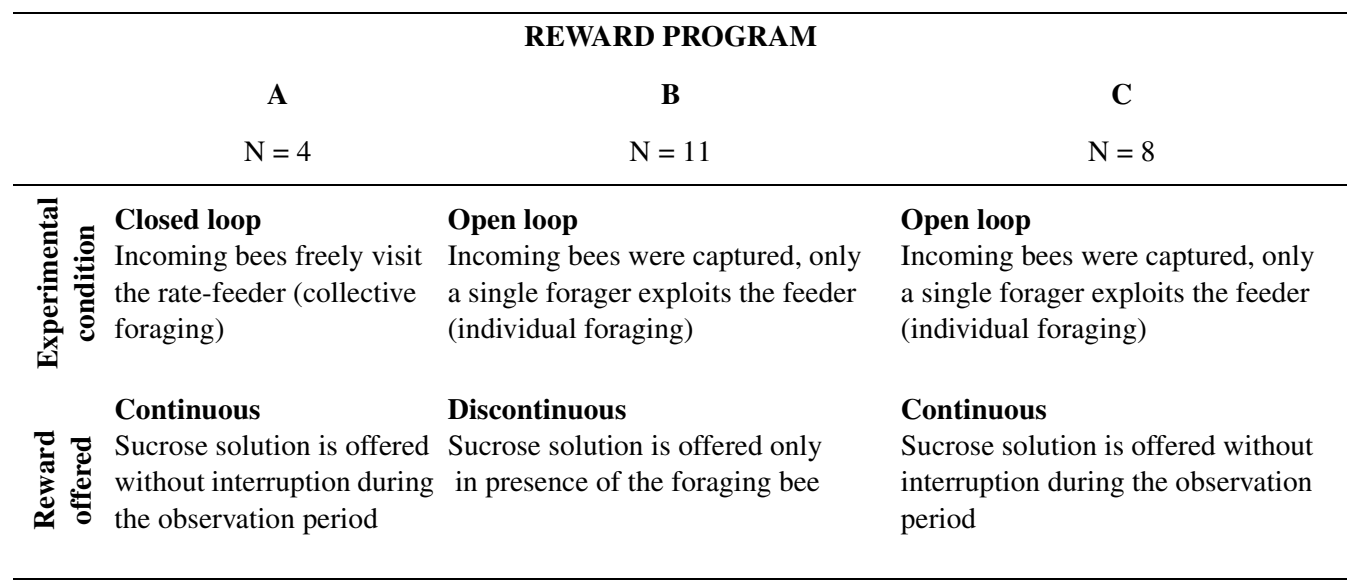

\subsection{Experimental series}

\subsubsection{First series: Behavioral responses during individual and collective foraging}

This series was designed to study the behaviors at the food source under open and closed-loop reward conditions (individual and collective foraging conditions, respectively). To analyze how a foraging team is built up when it exploits a rate-feeder, reward programs were offered at closed loop conditions (Tab. I, Program A). The rate-feeder offered a $1.8 \mathrm{M}$ sucrose solution at a continuous flow rate of $5.5 \mu \mathrm{L} / \mathrm{min}$ and incoming bees were allowed to freely visit it. Since the food source had a small and single opening and offered a low reward rate, resource competition and physical interference among bees of a foraging team occurred.

To compare collective foraging under Program A with individual foraging, we offered 2 additional experimental reward programs, Programs B and C, under open loop conditions (Tab. I). In these programs we selected one bee for the measurements (henceforth: single forager) while all of the incoming bees were caged. The selected bee was allowed to freely visit the rate-feeder, which offered sucrose solution $1.8 \mathrm{M}$ at a flow rate of $5.5 \mu \mathrm{L} / \mathrm{min}$. Its foraging activity was recorded during a 2-hour observation period. In Program B reward, the rate-feeder was switched off between feeding visits leading to a discontinuous reward rate. This procedure simulated competition because the single bee did not find accumulated sucrose solution between feeding-visits. In Program C reward, sucrose solution was delivered without interruptions along the 2-hours experimental period (i.e. allowing the accumulation of sucrose solution between feeding visits). During this procedure there was no competition for the resource even when the forager was absent from the rate-feeder. Since there were not a fixed number of labeled bees along the 2-months experimental period, reward programs were assigned alternately every day.

\subsubsection{Second series: Individual behavior during collective foraging}

This series was designed to study in detail the behavior of individual bees during collective foraging (Program A). It was performed in 2001 and only the A reward program was offered (see Tab. I). First, we quantified the number of previous foraging periods performed by each bee that arrived at the ratefeeder. To do this, the rate-feeder was switched on mornings and afternoons during a 2-hour period (henceforth: 2-hour foraging periods), and incoming bees were allowed to visit it freely. In each of these 2-hour foraging periods, the identity of the employed bees was registered. The apparatus was never switched on in the absence of the experimenter to control of the number of foragers and to identify all of the bees that were allowed access to the ratefeeder each day. Program A reward was offered 12 times within a 1-month experimental period in 2-hour foraging periods. The behavior of the foragers employed at the food source was video recorded by Panasonic Video Camera H 9000 and then analyzed by reproducing it in a Panasonic Video recorder AG-7355. 


\subsection{Measurements}

\subsubsection{First series of experiments}

For each labeled employed forager the following behavioral variables were measured at the ratefeeder:

Visitation time, in min, defined as the time the forager spent at the rate-feeder between two consecutive stays in the hive. During this time bees could fly up leaving the feeder and immediately return to feed or stay put (feeding or waiting) until returning to the hive.

Non-visitation time, in min, defined as the time elapsed between 2 successive visits.

Total foraging time, in min, defined as the time elapsed since the first arrival of the forager until the end of the observation period (total visitation + nonvisitation times). In the case of bees at single foraging (open loop conditions), the total foraging time coincided with the duration of the observation period.

Time at the rate feeder, in percentage, defined as the sum of time spent by a forager at the rate-feeder (on and around it) during all of its visits divided by total foraging time $\mathrm{x} 100$.

Frequency of visits, in number of visits per hour, for each bee was calculated as the number of visits performed during the observation period divided by its total foraging time.

\subsubsection{Second series of experiments}

For the second series, we measured other variables in addition to the variables previously mentioned for the first series of experiments, to analyze the individual behavior of the bees at collective foraging. We registered:

Previous Foraging Periods, defined as the number of previous 2-hour foraging periods in which each bee had been foraging at the rate-feeder before arriving in an observation period.

Feeding Index, measured for the first ten minutes of the first visit for each bee, calculated as the drinking time in minutes (i.e. the time the bee had its proboscis in contact with the sugar solution) divided by the measured period ( $10 \mathrm{~min}$ ). In the case a bee spent less than ten minutes during its first visit, the drinking time was divided by the duration of the visit. This variable determined the relative time during which the foraging bee effectively contacted the sucrose solution during the measured period. A value of feeding index $=1$, meant that bees contacted the sucrose solution without interruptions during this period. A value of feeding index $=0$, meant that bees did not contact the solution during the measured period, although it could be contacted later. Because the food source had a small single opening, no more than four bees could feed simultaneously. Therefore, when more than four bees were foraging together they had to alternate in order to drink.

Bees at Arrival, defined as the number of foragers simultaneously exploiting the rate-feeder when an incoming bee arrived there. It was defined only for the first minute of the first visit of each incoming bee. When arriving at the rate feeder, each incoming bee was able to contact the sucrose solution immediately or would have to wait depending on the number of simultaneously feeding foragers.

\subsection{Statistical analysis}

In the first series of experiments, the sample size was 23 observation periods and 50 foraging bees ( 11 and 8 individual bees from Programs $B$ and $C$ respectively, and 31 total incoming bees from 4 observation periods in Program A). Data were analyzed by means of Kruskal-Wallis rank analysis (Zar, 1984). In the second series of experiments, sample size was 12 observation periods and 137 foraging bees. Data were analyzed by means of Kruskal-Wallis, Dunn contrasts and Mann-Whitney U test (Zar, 1984). Correlations were performed by means of Pearson correlation matrices (131 data for frequency of visits and time at the food source or 45 in the case of feeding index).

\section{RESULTS}

\subsection{Behavioral responses during individual and collective foraging}

A regular pattern in the foraging-related variables (i.e. visits, non-visit times and frequency of foraging visits) was observed under open loop conditions ( $\mathrm{B}$ and $\mathrm{C}$ reward programs, Tab. II). In contrast, bees foraging under closed loop conditions displayed a great variability in these variables (Program A, Tab. II and Fig. 1), as shown by the large standard deviation values for all the variables measured for Program A only (Tab. II; Bartlett test, $P<0.0001)$. By focusing on each employed bee from a group, it was observed that as soon as more bees arrived at the feeder, their visitation time along the observation period increased (Fig. 1); while the number of foragers simultaneously exploiting the rate-feeder ranged from 2 to 5 bees (mode values).

To examine individual foraging patterns under both closed and open loop conditions, 


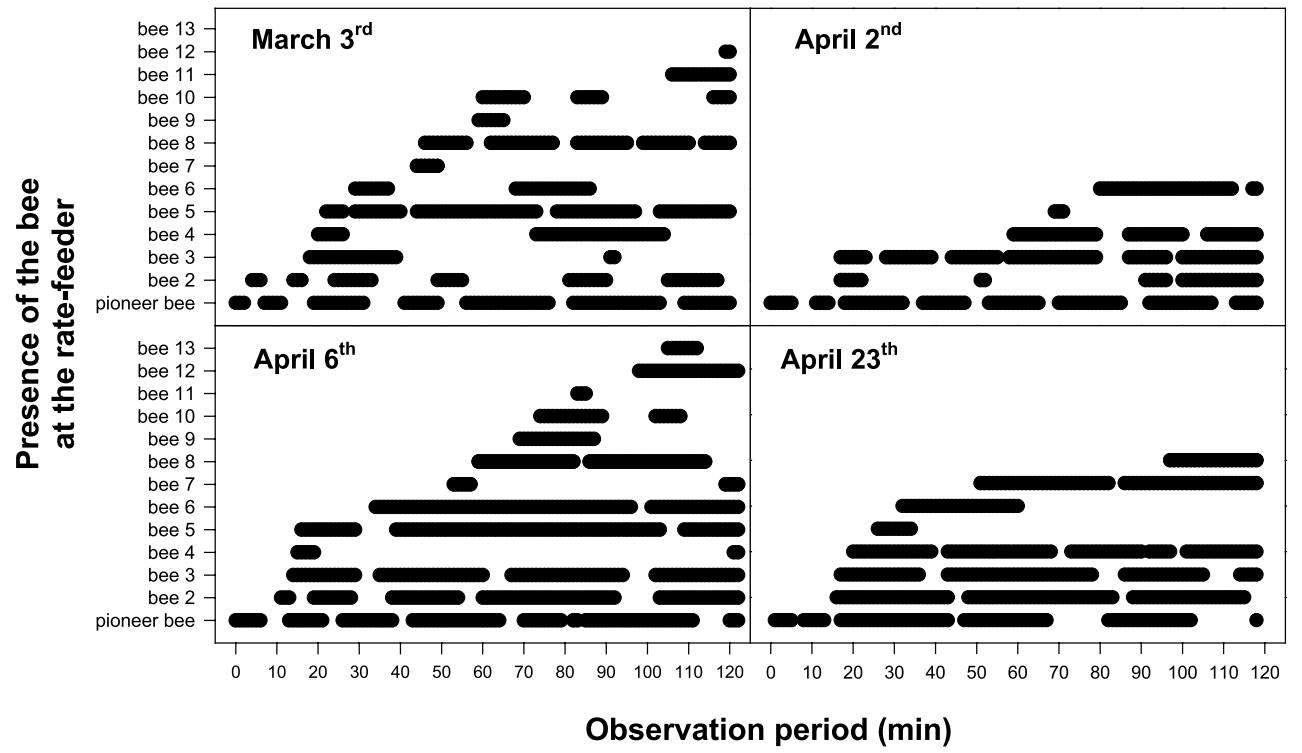

Figure 1. Visitation and non-visitation times during collective foraging under closed loop conditions (Program A). The behavior of each bee at the rate-feeder is shown along the observation period. Each graph shows the performance of a foraging team. "Pioneer bee" is the first forager visiting the rate-feeder during the observation period. "Bee 2", "bee 3" and so on, are the incoming bees according to the time of arrival. For each bee, visitation times are indicated by the size of the horizontal black bars and the space between them represent the non-visitation times.

Table II. Visitation, non-visitation times, and frequency of foraging visits (means \pm standard deviation) from bees collecting under different reward programs and experimental conditions: A (closed loop), B (open loop-discontinuous reward rate) and C (open loop-continuous reward rate).

\begin{tabular}{lccc}
\hline & \multicolumn{3}{c}{ REWARD PROGRAM } \\
& A & B & C \\
\hline Visitation time (min)\# & $16.5 \pm 12.9$ & $9.1 \pm 0.3$ & $5.9 \pm 0.5$ \\
Non-visitation time (min)£ & $16.1 \pm 22$ & $3.8 \pm 0.4$ & $3.4 \pm 0.1$ \\
Time at the rate-feeder (\%)* & $59 \pm 30$ & $73 \pm 3$ & $65 \pm 3$ \\
Frequency of visits (cycles/ & $2.9 \pm 2.4$ & $4.8 \pm 0.5$ & $6.7 \pm 0.9$ \\
hour) $¥$ & & &
\end{tabular}

Bartlett test for homogeneity of variances \# $\mathrm{Chi}^{2}{ }_{(2)}=60, P<0.0001$;

$$
\begin{aligned}
£ \mathrm{Chi}^{2}(2) & =97, P<0.0001 ; \\
* \mathrm{Chi}^{2}(2) & =17, P<0.0001 ; \\
¥ \mathrm{Chi}^{2}{ }_{(2)} & =32, P<0.0001 .
\end{aligned}
$$

Kruskal-Wallis Test \# $\mathrm{H}_{(2)}=10.1, P<0.01$; Dunn contrasts: A vs. C, $P<0.01$;

$£ \mathrm{H}_{(2)}=17.2, P<0.0001$; Dunn contrasts: in all cases, $P<0.05$;

$* \mathrm{H}_{(2)}=1.30, P=0.51$;

$¥ \mathrm{H}_{(2)}=23.9, P<0.0001 ;$ Dunn contrasts: A vs. B and A vs. C, $P<0.01$.

we analyzed the frequency of visits as a function of the time invested at the rate-feeder for each foraging bee exposed to the different reward programs (Fig. 2). The analysis showed that the frequency of visits increased with the decrement of competition at the food source (see also Tab. II, Kruskal-Wallis, $P<0.0001$ ). Clearly, bees from Program C (no competition) showed the highest frequency of visits (and the shortest visitation time, see Tab. II) 


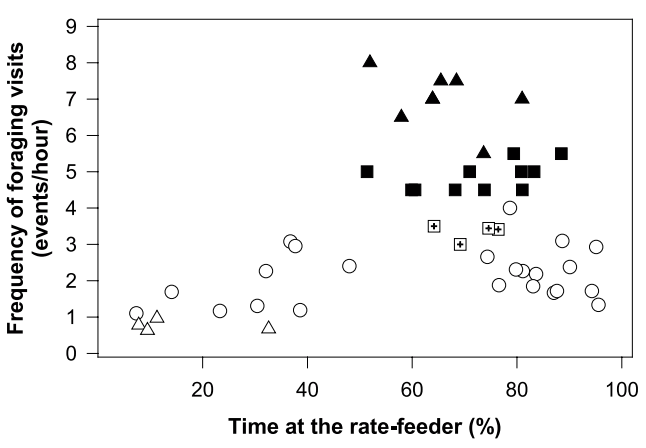

Figure 2. Frequency of foraging visits (events/hour) as a function of the time at the rate-feeder (in relative units, \%) for each forager. White symbols, bees from Program A: crossed-squares for pioneers, circles for non-pioneers and triangles for non-returning bees. Black squares, single bees from Program B. Black triangles, single bees from Program C. For statistical analysis see Table II. $\mathrm{N}=23$ observation periods, $n=50$ bees.

followed by bees from Program B, which is reasonable because the bees from Program $C$ found accumulated solution between visits. The mean time invested at the rate-feeder showed no significant differences (Fig. 2 and Tab. II, Kruskal-Wallis, $P=0.51$ ). In both programs under open loop conditions (i.e. individual foraging), bees spent around $70 \%$ of their foraging time (i.e. around $90 \mathrm{~min}$. of the 2-hour observation period) at the rate feeder. Under collective foraging conditions, a qualitative analysis showed that pioneers reached the highest frequency of visits compared with the rest of the group. They invested approx. $70 \%$ of their foraging time at the rate feeder. Moreover, approximately $13 \%$ of the incoming bees corresponded to "non-returning bees", which spent more than $90 \%$ of their foraging time off the rate-feeder, most probably at the hive. The behavior of non-pioneer bees was the most heterogeneous, with a portion of bees spending most of their time at the food source and the rest performing sporadic visits. This suggests that the interaction (i.e. competition) among bees employed at the food source strongly affected the individual behavior: while some bees increased their time at the food source, others increased their non-visitation time, and intermediate behaviors. From these results different kinds of employed bees were categorized according to their behavior while foraging in-group: (1) Pioneers, the first bee arrived at the rate feeder during the observation period, (2) Non-pioneers, defined as the incoming bees that landed after the pioneer but continued visiting the feeder during the observation period, and (3) Non-returning bees, bees that only made one visit within the first hour and did not return during the observation period. Bees that made only one visit within the second hour, and did not return to the food source until the end of the observation period were not considered for the subsequent analysis. This categorization was used for the analysis of the second experimental series.

\subsection{Individual behavior during collective foraging}

During the second experimental series, bees also showed great variability in their visitation and non-visitation times and in their frequency of visits, similar to the previous Program A reward (data not shown). The mode value was around 7 bees. Differences in the number of Bees at Arrival were not significant between non-pioneer and non-returning bees, while pioneers per definition always began to forage alone (Tab. III, Mann-Whitney, NS). In this case, only 8 of 12 observation periods began with a single employed forager (the rest began with 2 or 3 of them). We therefore defined only 8 pioneers. The frequency of visits and time at the rate feeder reached the highest values for pioneers, intermediate for non-pioneers and the lowest for non-returning bees (Tab. III). Pioneer bees performed more Previous Foraging Periods before the experimental series than the rest of the group, followed by non-pioneers and finally non-returning bees (Tab. III). Moreover, the number of Previous Foraging Periods performed well correlated with the time at the rate feeder, but not with the frequency of visits (Tab. IV). The feeding index varied between $0.94-1$ for pioneers, $0-$ 0.89 for non-pioneers and $0-0.07$ for nonreturning bees. These results indicated that pioneer bees were able to contact the sucrose solution immediately after arriving at the rate feeder, while non-returning bees did not (at least during the first $10 \mathrm{~min}$ of foraging). The feeding index also showed a greater range of values for non-pioneer bees, in comparison 
Table III. Foraging-related variables comparing pioneers, non-pioneers and non-returning bees of Program A. $n$ number of bees.

\begin{tabular}{lccc}
\hline Forager categories & Pioneers & Non-pioneers & Non-returning \\
\hline Bees at Arrival \# & 0 & $5.5 \pm 0.3$ & $6.6 \pm 1$ \\
& $(n=8)$ & $(n=114)$ & $(n=15)$ \\
Frequency of Visits $¥$ & $2.7 \pm 0.18$ & $1.8 \pm 0.05$ & $0.7 \pm 0.03$ \\
(foraging visits/hour) & $(n=8)$ & $(n=113)$ & $(n=15)$ \\
Time at the rate-feeder (\%) & $84 \pm 1$ & $67 \pm 2$ & $7 \pm 1$ \\
& $(n=8)$ & $(n=114)$ & $2.3 \pm 0.3$ \\
Previous Foraging Periods* & $8.4 \pm 1.5$ & $6.5 \pm 0.4$ & $(n=15)$ \\
\end{tabular}

\# Mann-Whitney $\mathrm{U}$ test between non-pioneers and non-returning bees: $\mathrm{U}_{2}=715.5, P=0.3$;

$¥$ Kruskal-Wallis: $\mathrm{H}_{2}=53.8, P<0.00001$;

$\S$ Kruskal-Wallis: $\mathrm{H}_{2}=40.1, P<0.00001$;

* Kruskal-Wallis: $\mathrm{H}_{2}=21.5, P<0.00001$.

Table IV. Pearson correlations among foraging-related variables: Previous Foraging Periods, Frequency of Visits, Time at the rate-feeder and Feeding Index. $r=$ correlation coefficient, $P=$ significance level, $n=$ number of bees.

\begin{tabular}{lcccc}
\hline & & Frequency of Visits & Time at the rate- feeder (\%) & Feeding Index \\
\hline Previous Foraging Periods & $r$ & -0.083 & 0.510 & 0.691 \\
$n=132$ & $p$ & 0.933 & 0.003 & 0.001 \\
Feeding Index & $r$ & 0.880 & 0.932 & \\
$n=45$ & $p$ & $<0.0001$ & $<0.0001$ & \\
\hline
\end{tabular}

with pioneers or non-returning bees. Although the Feeding Index was calculated only for the first 10 minutes of the first visit for each bee, we observed a significant correlation with time at the rate feeder, frequency of visits and number of Previous Foraging Periods (Pearson correlation test, $P<0.001$, Tab. IV). As a whole, these results suggest that bees that had more Previous Foraging Periods contacted the sucrose solution for more time and had higher frequency of visits at the rate feeder.

\section{DISCUSSION}

Bees foraging alone performed regular visits to the rate-feeder. This result was expected since it is known that visitation time depends greatly on the reward conditions at the food source (i.e. flow rate and concentration of the sucrose solution offered, Núñez, 1982; von Frisch, 1967). A different situation was observed among bees foraging collectively: the increasing number of foragers that exploited the feeder throughout the time decreased the reward conditions found by each of the individual bees collected at the feeder, and increased the physical interactions among employed bees, which led to an increase in the intraspecific competition for the resource exploited. Thus, the appearance of interactions among workers was well correlated with the diversity of the individual foraging patterns observed in the group. A similar situation was observed under natural conditions. von Frisch (1967) observed that a decrease in nectar production of flowers led to different responses within a team of foragers: some of them continued foraging, others spent more time at the hive and others followed dances for more profitable-food sources or looked for alternative ones. A diversification of the foraging patterns was also observed in stingless bees Mellipona fasciata, especially when collecting at food sources of low profitability (Biesmeijer and Ermers, 1999), and in bumblebees as a consequence of competition (Heinrich, 1979). As a 
whole, these results suggest that when the profitability of the food source diminishes as a consequence of the decrease in the nectar flow or the increase in the intraspecific competition, interindividual differences in behavioral foraging patterns appear. This assumption matches the notion that bees sampling poor flowers increase their flight distances or quit, while bees sampling rich ones exhibit local searches (Heinrich, 1979; Thomson et al., 1982; Keasar et al., 1996).

The number of Previous Foraging Periods was one of the behavioral parameters that was best correlated with the observed foraging patterns. Although we did not control the experience of each bee from the beginning of their foraging life, we assumed that the number of Previous Foraging Periods correlated positively with the foraging experience at the experimental feeder. Following this assumption, it seems that the foraging experience of a bee at a food source affected the bee's individual behavioral response: when a group of foragers exploited a food source, pioneers were the bees with most experience at the feeder, followed by non-pioneers and finally non-returning bees. Pioneer bees tended to persist more in the searching for food at the feeding place, a situation observed by their high values of Feeding Index and time invested at the feeder. von Frisch (1967) proposed that the strength of the floral constancy (the capacity of bees to bias their foraging activity in a particular floral species) differs between individuals. Our data additionally suggest that foraging experience at a particular food source could be the factor that directly affects the persistency of collecting food at this feeding site. This suggestion is supported by observations by Free (1967), who pointed out that experienced bees become conditioned to color and odor of flowers and (often) return to only a small area within an agricultural crop on successive trips, even during different days, which increases their efficiency when searching a food source. Similarly, once bumblebees have established a particular flight path through a stand of flowers, they will persistently follow that path despite changes in the arrangement of the flowers (Thomson, 1996). It was further suggested that long term experience strongly influence flight distances (Keasar et al., 1996; Capaldi et al., 2000). In addition, differences were found in the level of recruitment depending on prior foraging experience. Gil and Farina (2002) showed that temporally inactive foragers need fewer social interactions within the hive to be reactivated at a known food source if they have already visited this site several times.

During collective foraging, we observed a high range of variation for the Feeding Index (from 0 to 1 ), which suggests that each bee contacted the sucrose solution differently. Consequently, although bees collected together at the same food source, intake rates and final crop loads could vary from one bee to another. It would depend on the time contacting the sucrose solution and the time spent at the food source. Therefore, the differences found among individual foraging patterns could emerge from differences in the intake rates perceived and crop loads ingested by each employed bee. Higher nectar volumes per time could be attained by the most experienced foragers (i.e. pioneers), which have learned how to handle the flower and to obtain the food achieving higher efficiency as nectar carriers under known foraging conditions. This suggestion is supported by findings from Dukas and Visscher (1994) who observed that under natural conditions, most experienced bees arrived to the hive from the food source with higher crop loads. Lower nectar volumes per time could be attained by non-returning and non-pioneers bees. This assumption matches the idea that bees sampling poor flowers go elsewhere or quit, as was shown in bees and bumblebees that move a larger distance after receiving a small reward or no reward at all (Heinrich, 1979; Waddington, 1980; Thomson et al., 1982; Keasar et al., 1996).

The high diversity of behavioral patterns observed could be advantageous not only for the foraging team, but also for the colony as a whole. Pioneer bees would behave as food carriers facilitated by their foraging experience at their food source. Non-returning bees or those bees that performed sporadic visits could invest higher times at the hive, enhancing the possibility of being recruited to other food sources while they monitor the possibility of an increase in profitability of known food sources (Núñez, 1982). As an example, it was observed the same bee behaving as a "nonreturning" during its first two Previous Foraging Periods at the rate feeder belonged to "pioneer" 
after ten Previous Foraging Periods. This observation indicates that some non-returning bees performed long pauses in the colony but did not definitively abandon the food source, and according to an increase in their foraging experience at the site, they changed their foraging pattern while collecting in a group. Finally, several non-pioneer bees invested a high percentage of time at the food source but also had high exploratory activity, which meant that they did not search for sucrose solution only at the rate feeder, but explored around the feeding platform (Fernández, personal observation). This behavior is relevant for foraging teams because it enhances the possibility of discovering new resource opportunities near known food sources (Núñez, 1977). Similarly, some bumblebees following foraging routes occasionally sample other plants, if those prove rewarding they are more likely to be visited on subsequent pass (Thomson et al., 1982, 1987).

In summary, during collective foraging employed bees interfered with one another at the food source. This interference affected individual foraging behaviors that would be modulated by the previous foraging experience of each individual. Most experienced bees could access the food more readily, attaining higher intake rates and greater crop loads, which in turn would lead to a high persistence at the food source and a high efficiency as carriers of nectar at the hive. Less experienced bees would attain lower crop loads spending more time at the hive, which would enhance the possibility of being recruited to more profitable food sources. Therefore, by means of different behavioral patterns performed by the members of the same foraging team, honeybee hives may improve their foraging efficiency, which may allow more flexibility during the collective resource exploitation according to the nectar availability currently presents.

\section{ACKNOWLEDGEMENTS}

We are deeply indebted to J.A. Núñez and R.J. De Marco for valuable comments and suggestions throughout the study. This study was partially supported by funds from ANPCYT to WMF and Fundación Antorchas, University of Buenos Aires and CONICET to both authors. The present study com- plies with the current laws of the state country in which experiments were performed.

Résumé - Butinage collectif de nectar par l'Abeille domestique (Apis mellifera) en conditions de faible récompense. Le comportement de coopération chez les insectes sociaux fait partie d'un système complexe dans lequel des facteurs tels que l'état interne de la colonie et de ses individus, les signaux de communication et les variables du milieu influencent, parmi d'autres, la performance des tâches individuelles. Cela conduit à analyser le comportement individuel dans le contexte collectif. Lorsqu'un groupe d'abeilles exploite simultanément une source de nourriture de faible récompense, les butineuses doivent entrer en compétition pour obtenir la ressource. Le but de cette étude est de comparer le comportement de butinage des abeilles dans des conditions de non compétition (butinage individuel) et de forte compétition (butinage collectif). Nous avons axé notre étude durant la période de temps pendant laquelle une abeille individuelle commence à récolter de la nourriture jusqu'au moment où un groupe de butinage est formé. Les abeilles butinaient une solution de saccharose à $1,8 \mathrm{M}$ délivrée à un débit de $5,5 \mu \mathrm{L} / \mathrm{min}$ à travers une ouverture unique, ce qui créait une situation de compétition pour l'accès à la nourriture. Le comportement de ces abeilles butinant en groupe a été comparé à celui des abeilles qui exploitaient le même nourrisseur mais individuellement (Tab. I). Un schéma régulier dans la visite, dans les périodes de non visite et dans la fréquence des périodes de visite a été observé chez les abeilles qui butinaient individuellement (voir l'écart-type dans le Tab. II). Cette réponse était indépendante du fait que le programme de récompense sur le nourrisseur soit ou non continu (c'est-à-dire que le nourrisseur délivre la solution seulement en présence de butineuses ou même en leur absence). Lorsque les abeilles butinaient en groupe, elles présentaient une grande variabilité dans leur comportement (voir l'écart-type dans le Tab. II). Certaines abeilles effectuaient des visites régulières au nourrisseur, tandis que d'autres ne venaient que sporadiquement (Figs. 1 et 2). Les abeilles qui avaient un schéma temporel le plus régulier étaient celles qui arrivaient les premières sur le nourrisseur (les "pionnières ») et elles passaient plus de temps à ingérer la solution. Les autres abeilles présentaient soit des fréquences de visite plus faibles tout en continuant à revenir au nourrisseur (définies comme « non pionnières »), soit ne visitaient le nourrisseur qu'une seule fois au cours de la période d'observation de $2 \mathrm{~h}$ (définies comme «ne récidivant pas »). Ce classement, lié à la persistance du butinage, était bien corrélé avec l'expérience préalable de butinage sur le site (Tabs. III et IV). Dans l'ensemble, ces résultats suggèrent qu'en cas de butinage en groupe les abeilles les plus expérimentées obtiendront des charges plus élevés, ce qui les conduit en retour à avoir une forte persistance à la source et une efficacité élevée comme rapporteuses de nectar à la ruche. 
Les abeilles moins expérimentées rapporteraient de plus faibles charges et passeraient plus de temps à la ruche, ce qui augmenterait leur possibilité d'être recrutées pour des sources de nourriture plus intéressantes. Les différents schémas comportementaux des individus d'une équipe de butineuses permettent donc aux colonies d'abeilles d'améliorer leur efficacité de butinage et contribuent à une plus grande flexibilité pendant l'exploitation collective d'une source de nourriture en fonction de l'offre en nectar présente à ce moment là.

\section{Apis mellifera / butinage collectif / compétition / insecte expérimenté}

Zusammenfassung - Sammeln in Gruppen von Honigbienen (Apis mellifera) unter Bedingungen niedriger Belohnung. Kooperatives Verhalten bei sozialen Insekten ist Teil eines komplexen Systems, in dem Faktoren wie der innere Zustand der Kolonie oder seiner Einzeltiere, Kommunikationssignale und Umgebungsvariablen die individuelle Aufgabenerfüllung bestimmen. Daraus ergibt sich die Notwendigkeit, das individuelle Verhalten im Kontext des Kollektivs zu untersuchen. Wenn eine Bienengruppe gleichzeitig eine Futterquelle geringer Ergiebigkeit ausbeutet, müssen die Sammlerinnen um die Ressource wetteifern. Das Ziel dieser Untersuchung war, das Sammelverhalten von Bienen unter nicht-kompetitiven (einzeln) oder kompetitiven (in Gruppen) Bedingungen zu vergleichen. Wir konzentrierten unsere Untersuchung auf das Zeitintervall zwischen dem Beginn des Sammelns durch eine einzelne Biene und der Ausbildung einer Sammelgruppe. Die Bienen in dem Experiment sammelten 1,8 M Zuckerlösung, die mit einer Flussrate von $5,5 \mu \mathrm{L} / \mathrm{min}$ durch eine einzige Trinköffnung angeboten wurde. Diese Situation zwingt die Bienen zu einer Auseinandersetzung über den Zugang zur Nahrungsquelle. Das Verhalten kollektiv sammelnder Bienen wurde mit dem von einzeln sammelnden Bienen an der gleichen Futterstelle verglichen (Tab. I). Bei den einzeln sammelnden Bienen konnte ein regelmäßiges Muster des Futterquellenbesuchs, der Zeiten ohne Besuch und der Häufigkeit der Sammelereignisgruppen beobachtet werden (siehe Standardabweichung in Tab. II). Diese Verhaltensantwort war davon unabhängig, ob an der Futterstelle ein gleichmäßiges oder ungleichmäßiges Futterprogramm geboten wurde (d.h. die Futterstelle lieferte das Futter nur in Gegenwart oder sogar nur bei Abwesenheit von Sammlerinnen). Beim Sammeln in Gruppen war das Verhalten der Bienen sehr unterschiedlich (siehe Standardabweichung in Tab. II). Einige Bienen besuchten die Futterstelle mit hoher Regelmäßigkeit, während andere nur verstreute Sammelereignisgruppen (Abb. 1 und 2) ergaben. Die Bienen mit den regelmäßigsten zeitlichen Mustern waren die, die zuerst an der Sammelstelle erschienen waren (,Pioniere“) und die mehr Zeit investiert hatten, um die Futterlösung aufzusaugen. Der
Rest der Gruppe besuchte die Futterstelle entweder mit geringerer Häufigkeit, fuhr aber fort zu der Futterstelle zurückzukehren (,Nicht-Pioniere“), oder sie besuchten die Futterstelle innerhalb der Beobachtungszeit von 2 Stunden nur einmal (,Nichtrückkehrer"). Diese auf die Sammelbeständigkeit an der Futterstelle bezogene Einteilung korrelierte hoch mit der anfänglichen Sammelerfahrung an dieser Stelle (Tab. III und IV). Im Ganzen gesehen legen die Ergebnisse nahe, dass die erfahrensten Bienen während des Sammelns höhere Futteraufnahmeraten und Kropffüllungen erreichen, was dann wiederum zu höherer Beständigkeit an der Futterquelle und höherer Effizienz im Nektartransport zu dem Nest führt. Bienen mit geringerer Erfahrung würden geringere Kropffüllungen erreichen und längere Zeit im Nest verbringen, was dann die Wahrscheinlichkeit erhöht, dass sie zur Ausbeutung von profitableren Futterstellen rekrutiert werden. Hierdurch könnte das unterschiedliche Verhalten der Einzeltiere innerhalb von Gruppen die Sammeleffizienz von Honigbienenvölkern verbessern und $\mathrm{zu}$ einer höheren Flexibilität während der gemeinsamen Ausbeutung des zu einem Zeitpunkt gegebenen Nektarangebotes beitragen.

Apis mellifera / Honigbienen / Erfahrung / kollektives Sammeln / Konkurrenz

\section{REFERENCES}

Beshers S.N., Robinson G.E., Mittenthal J.E. (1999) Response thresholds and division of labor in insect colonies, in: Detrain C., Deneubourg J.L., Pasteels J.M. (Eds.), Information processing in social insects, Birkhäuser Verlag, Berlin, pp. 115-139.

Biesmeyer J.C., Ermers M.C.W. (1999) Social foraging in stingless bees: how colonies of Melipona Fasciata choose among nectar sources, Behav. Ecol. Sociobiol. 46,129-140.

Camazine S., Visscher P.K., Finley J., Vetter R.S. (1999) House-hunting by honey bee swarms: collective decisions and individual behaviors, Insectes Soc. 46, 348-360.

Camazine S., Deneubourg J.L., Franks N.R., Sneyd J., Theraulaz G., Bonabeau E. (2001) Self organization in Biological Systems, Princeton University Press, Princeton, New Jersey and Oxford.

Capaldi E.A., Smith A.D., Osborne J.L., Fahrbach S.E., Farris S.M., Reynolds D.R., Edwards A.S., Martin A., Robinson G. E., Poppy G.M., Riley J.R (2000) Ontogeny of orientation flight in the honeybee revealed by harmonic radar, Nature 403 , 537-540.

Dukas R., Visscher P.K. (1994) Lifetime learning by foraging honeybees, Anim. Behav. 48, 10071012.

Free J.B. (1967) The foraging behavior of bees and its effect on the isolation and speciation of plants, in: Reproductive biology and taxonomy of vascular 
plants, Report of the conference held by the botanical society of the British Isles at Birmingham University, Pergamon Press, New York, pp. 76-92.

Frisch K. von (1967) The Dance Language and Orientation of Bees, Harvard University Press, Cambridge, Mass.

Gil M., Farina W. M. (2002) Foraging reactivation in the honeybee Apis mellifera $\mathrm{L}$.: factors affecting the return the return to known nectar sources, Naturwissenschaften, 89, 322-325.

Heinrich B. (1979) Foraging optimization by individual initiative, in: Bumble bee economics, Harvard University Press, Mass., pp. 123-146.

Keasar T., Schimda A., Motro U. (1996) Innate movement rules in foraging bees: Flight distances are affected by recent rewards and are correlated with choice of flower type, Behav. Ecol. Sociobiol. 39, 381-388

Makino T.T., Sakai S. (2004) Findings of spatial foraging patterns of bumblebees (Bombus ignites) from a bee-tracking experiment in a net cage, Behav. Ecol. Sociobiol. 56, 155-163.

Núñez J.A. (1970) The relationship between sugar flow and foraging and recruiting behaviour of honey bees (Apis mellifera L.), Anim. Behav. 18 , 527-538.

Núñez J.A. (1971a) Simulador para estudios del aprendizaje en la abeja Apis Mellifera L., Acta Cient. Venez. 22, 101-106.

Núñez J.A. (1971b) Beobachtungen an Sozialbezogenen Verhaltensweisen von Sammelbienen, Z Tierpsychol. 28, 1-18.

Núñez J.A. (1973) El comportamiento recolector de la abeja Apis mellifera L.: Un estudio cuantitativo del comportamiento, in: Barbieri, Legname (Eds.), Progresos en biología, IV Congreso Argentino Biología, pp. 225-234.

Núñez J.A. (1977) Nectar flow by melliferous flora and gathering flow by Apis mellifera ligustica, J. Insect Physiol. 23, 265-275.

Núñez J.A. (1982) Honeybee foraging strategies at a food source in relation to its distance from the hive and the rate of sugar flow, J. Apic. Res. 21, 139150.
Oldroyd B.P., Rinderer T.E., Buco S.M. (1992) Intra colonial foraging specialism by honey bees (Apis mellifera) (Hymenoptera: Apidae), Behav. Ecol. Sociobiol. 30, 291-295.

Pleasants J.M., Zimmerman M. (1979) Patchiness in the dispersion of nectar resources: evidence for hot and cold spots, Oecologia (Berl.) 30, 172-177.

Pleasants J.M., Zimmerman M. (1983) The distribution of standing crop of nectar: what does it really tell us, Oecologia (Berl.) 46, 301-303.

Seeley T.D. (1995) The wisdom of the hive, Harvard University Press, Cambridge, Mass.

Seeley T.D., Visscher P.K. (2004) Group decision making in nest-site selection by honey bees, Apidologie 35, 101-116.

Seeley T.D., Camazine S., Sneyd J. (1991) Collective decision-making in honeybees: how colonies choose among nectar sources, Behav. Ecol. Sociobiol. 28, 277-290.

Thomson J.D. (1996) Trapline foraging by bumblebees. 1. Persistence of flight-path geometry, Behav. Ecol. 7, 158-164

Thomson J.D., Maddison W.P., Plowright R.C. (1982) Behavior of bumble bees pollinators of Aralia hispida vent. (Araliacea), Oecologia (Berl.) 54, 326-336.

Thomson J.D., Peterson S.C., Harder L.D. (1987) Response of traplining bumble bees to competition experiments: shifts in feeding location and efficiency, Oecologia (Berl.) 71, 295-300.

Vogel S. (1983) Ecophysiology of zoophilic pollination, in: Lange O.L., Nobel P.S., Osmond C.B., Ziegier H. (Eds.), Physiological plant ecology III, Encyclopedia of Plant Physiology, Springer, Berlin, Heidelberg, New York, pp. 559-624.

Waddington K.D. (1980) Flight patterns of foraging honeybees in relation to artificial flower density and distribution of nectar, Oecologia (Berl.) 33, 88-193.

Zar J.H. (1984) Biostatistical analysis, 3rd ed., Prentice-Hall International, New Jersey.

Zimmerman M. (1981) Patchiness in the dispersion of nectar resources: probable causes, Oecologia (Berl.) 38, 43-46. 